Andrzejewska Marta, Lubarska Marta, Czerwik Jakub, Kipka Anna, Kowalczuk Klaudia. The current knowledge on ASXL1mutated acute myeloid leukemia. Journal of Education, Health and Sport. 2022;12(2):27-33. eISSN 2391-8306. DOI http://dx.doi.org/10.12775/JEHS.2022.12.02.003

https://apcz.umk.pl/JEHS/article/view/JEHS.2022.12.02.003

https://zenodo.org/record/5956058

The journal has had 40 points in Ministry of Education and Science of Poland parametric evaluation. Annex to the announcement of the Minister of Education and Science of December 1, 2021. No. 32343. Has a Journal's Unique Identifier: 201159. Scientific disciplines assigned: Physical Culture Sciences (Field of Medical sciences and health sciences); Health Sciences (Field of Medical Sciences and Health Sciences).

Punkty Ministerialne z 2019 - aktualny rok 40 punktów. Załącznik do komunikatu Ministra Edukacji i Nauki z dnia 1 grudnia 2021 r. Lp. 32343. Posiada Unikatowy Identyfikator Czasopisma: 201159. Przypisane dyscypliny naukowe:Nauki o kulturze fizycznej (Dziedzina nauk medycznych i nauk o zdrowiu); Nauki o zdrowiu (Dziedzina nauk medycznych i nauk o adrowiu).

(c) The Authors 2022;

This article is published with open access at Licensee Open Journal Systems of Nicolaus Copernicus University in Torun, Poland

Open Access. This article is distributed under the terms of the Creative Commons Attribution Noncommercial License which permits any noncommercial use, distribution, and reproduction in any medium,

provided the original author (s) and source are credited. This is an open access article licensed under the terms of the Creative Commons Attribution Non commercial license Share alike.

(htp://creative The authors declare that there is no conflict of interests regarding the publication of this paper.

Received: 20.01.2022. Revised: 25.01.2022. Accepted: 03.02.2022.

\title{
The current knowledge on ASXL1-mutated acute myeloid leukemia
}

\author{
Marta Andrzejewska ${ }^{1}$, Marta Lubarska $^{1}$, Jakub Czerwik ${ }^{1}$, Anna Kipka ${ }^{1}$, Klaudia Kowalczuk ${ }^{1}$
}

${ }^{1}$ Faculty of Medicine, Poznan University of Medical Sciences

\begin{abstract}
Abstrakt
Ostra białaczka szpikowa jest nowotworem złośliwym układu krwiotwórczego, w patogenezie której centralną rolę pełnią mutacje genów kontrolujących dojrzewanie i apoptozę komórek progenitorowych szpiku. Istotna rokowniczo jest mutacja w genie $A S X L 1$, którego produkt białkowy bierze udział $\mathrm{w}$ regulacji ekspresji genów. Jest ona negatywnym czynnikiem prognostycznym i predykcyjnym. Szacuje się, że mutacja genu ASXL1 występuje u 14,419,1\% pacjentów z AML i jest częstsza u mężczyzn powyżej 60 roku życia. Aberracje chromosomów 8 i 11 często współwystępują z mutacją genu $A S X L 1$ w AML i mogą stanowić dodatkową, istotną prognostycznie informację. Leczenie chorych z AML dopasowywane jest do pacjenta w zależności od grupy ryzyka, zmian kariotypu oraz współistniejących mutacji. Duża liczba chorych nie kwalifikuje się do allo-HSCT, choć ta metoda znacznie poprawia przeżywalność pacjentów z AML z mutacją genu ASXL1. Zastosowanie w terapii tych pacjentów może mieć również gilterytynib, jednak mnogość towarzyszących mutacji zmusza do bazowania na chemioterapii opartej na niespecyficznych lekach cytotoksycznych. Celem pracy jest podsumowanie najważniejszych informacji dotyczących patogenezy, cech szczególnych, diagnostyki i terapii AML z współistniejącą mutacją ASXL1.
\end{abstract}

\section{Słowa kluczowe: ostra bialaczka szpikowa, ASXL1, mutacja, AML, nowotwory szpikowe}

\begin{abstract}
Acute myeloid leukemia is a malignant hematopoietic cancer, in the pathogenesis of which the central role is played by the mutations of genes controlling maturation and apoptosis of bone marrow progenitor cells. A mutation in the ASXL1 gene, whose protein product takes part in the regulation of gene expression, is of prognostic importance, being a negative prognostic and predictive factor. It is estimated that the ASXL1 gene mutation occurs in 14.4$19.1 \%$ of patients with AML and is more frequent in men over 60 years of age. Aberrations of
\end{abstract}


chromosomes 8 and 11 often co-occur with $A S X L 1$ gene mutation in AML and may provide additional prognostically relevant information. Treatment of patients with AML is tailored to the patient depending on the risk group, karyotype aberrations and coexisting mutations. Many patients are not eligible for allo-HSCT, although this method significantly improves the survival of AML patients with $A S X L 1$ gene mutations. Gilteritinib may also be used to treat these patients, but the multitude of associated mutations forces to rely on chemotherapy based on non-specific cytotoxic drugs. This review summarizes the most crucial information concerning the pathogenesis, peculiarities, diagnosis and therapy of AML with coexisting ASXL1 mutation.

\section{Key words: acute myeloid leukemia, ASXL1, mutation, AML, myeloid neoplasms}

\section{Wstęp}

Ostra białaczka szpikowa (AML, ang. acute myeloid leukemia) to zróżnicowany genetycznie nowotwór złośliwy układu krwiotwórczego, wywodzący się ze zmienionych nowotworowo komórek progenitorowych mielopoezy (1). Mediana wieku chorych w momencie rozpoznania wynosi 70 lat (2). W 2017 roku dokonano rewizji klasyfikacji WHO AML i pokrewnych nowotworów mieloidalnych, wyodrębniając postaci $\mathrm{z}$ obecnymi charakterystycznymi zmianami cytogenetycznymi i molekularnymi (3). Klasyfikacja ta ma charakter rozwojowy i podlega ciągłym zmianom, dzięki wynikom nowych badań oceniających wpływ poszczególnych aberracji na przebieg kliniczny, odpowiedź na stosowane leczenie i rokowanie $\mathrm{u}$ chorych na AML. Jedną z takich aberracji są mutacje genu ASXL1 (ang. additional sex combs like 1) (4).

Gen ASXL1 znajduje się w rodzinie genów odpowiadających za regulację epigenetyczną i ekspresję genów (5). Uważa się, że fizjologicznie pełni on rolę antyonkogenu (5). Znajduje się W prążku 11 długiego ramienia chromosomu 20 (20q11.21) (5). Mutacje tego genu występują przede wszystkim $\mathrm{w}$ eksonie $12 \mathrm{i}$ zazwyczaj są to zmiany $\mathrm{w}$ układzie heterozygotycznym $(5,6)$. Dominują mutacje przesunięcia ramki odczytu lub nonsensowne $(5,6)$.

Postuluje się, że mutacje $A S X L 1$ zachodzą na początkowym etapie leukemogenezy, mając znaczenie dla dalszego rozwoju choroby (5). Częstość jej występowania to około 14,4-19,1\% w ogóle populacji pacjentów z AML $(5,7)$, jednak dane literaturowe wskazują, że występuje ona znacząco częściej w przypadku pacjentów cierpiących na AML wtórną do innej choroby hematologicznej (sec-AML, ang. secondary acute myeloid leukemia). W populacji pacjentów z sec-AML do chorób takich jak np. zespół mielodysplastyczny (MDS, ang. myelodysplastic syndrome) czy przewlekła białaczka szpikowa (CML, ang. chronic myeloid leukemia) mutacja ta może występować z częstością nawet aż 32.9\% (5).

Zważając na istotne implikacje obecności mutacji genu $A S X L 1$ u pacjentów z rozpoznaniem AML, badanie tego genu wydaje się być istotne w początkowej, rutynowej diagnostyce molekularnej choroby. W obecnie obowiązujących zaleceniach polskich za podstawowe badanie genetyczne uważa się badanie kariotypu (8), często wykonuje się także badania genów NPM1 i FLT3 ze względu na możliwość personalizacji terapii $(2,8)$. Biorąc pod uwagę wpływ mutacji $A S X L 1$ na przebieg choroby, jej wykrycie może pozwolić na dokładną stratyfikację ryzyka u pacjenta oraz wdrożenie najlepszej możliwej terapii. Niniejsza praca skupi się na roli genu $A S X L 1 \mathrm{w}$ patogenezie AML, a także cechach AML z obecną mutacją 
genu ASXL1, jej wpływie na rokowanie oraz możliwych odrębnościach w terapii u takich pacjentów.

\section{Implikacje kliniczne obecności mutacji $A S X L 1$ u pacjentów z AML}

Rolą genu $A S X L 1$ jest kodowanie białek zaangażowanych w regulację struktury chromatyny jego produkt białkowy uczestniczy w m.in. usuwaniu ubikwityny z histonu H2A (9). Według najnowszych doniesień białko $A S X L 1$ wpływa, wraz z kompleksem białek PRC2 (ang. polycomb repressor complex 2), na potrójną metylację histonu H3K27. W wyniku wzajemnych oddziaływań dochodzi do hamowania transkrypcji (10). Kompleks ten reguluje odpowiedź na uszkodzenie DNA, co w kontekście zarówno AML, jak i innych chorób nowotworowych działa jak bariera przeciwko niekontrolowanym podziałom komórek (11).

Badania wykazały, że mutacja genu ASXL1 prowadzi do upośledzenia hematopoezy oraz przyspiesza progresję nowotworów szpiku kostnego, poprzez utratę interakcji z kompleksem białek PRC2 (6). Z uwagi na to, że mutacja w genie $A S X L 1$ powoduje utratę funkcji białka, nie dochodzi wówczas do hamowania transkrypcji.

Mechanizmy łączące gen $A S X L 1$ z patogenezą AML nie zostały jeszcze w pełni wyjaśnione, tak samo jak jego znaczenie w prognozie choroby. Wiadomo, że mutacja ta wiąże się $\mathrm{z}$ gorszym rokowaniem u chorych na AML i tacy chorzy automatycznie kwalifikowani są do grupy wysokiego ryzyka (2). Wyjściowa ocena rokowania jest niezbędna do ustalenia postępowania, które daje największą szansę na wyleczenie, przy jednoczesnym zmniejszeniu ryzyka związanego z leczeniem. Aby dobrać najodpowiedniejszą terapię, należy również wziąć pod uwagę stan sprawności, obecność chorób współistniejących oraz wiek chorego (2).

\section{Wspólwystępowanie mutacji w genie $A S X L 1$ z aberracjami cytogenetycznymi}

Heterozygotyczne mutacje genu $A S X L 1$, w szczególności te zlokalizowane w eksonie 12, współwystępują z charakterystycznymi zaburzeniami cytogenetycznymi (5). Obecne są one głównie u chorych starszych (mediana wieku 72 lata) (5). Szczególnie często zmiany te wydają się występować w skojarzeniu $\mathrm{z}$ aberracjami chromosomu 8 i 11 pary, do których należą m.in. trisomia $8, \mathrm{t}(8 ; 21)$, trisomia 11 , del $11 \mathrm{q}, \mathrm{t}(11)$ i $\operatorname{add}(11 \mathrm{p})$ (5). Trisomia chromosomu 8 wykrywana jest u $10-15 \%$ pacjentów z AML z towarzyszącymi zmianami w kariotypie, jednak mutacja ta nie jest charakterystyczna dla AML i występuje istotnie często na przykład w MDS czy CML. Ponadto aberracja ta wiąże się z wyższym wiekiem zachorowania w porównaniu do braku tej mutacji (12). Z tego powodu wysunięto hipotezę, że stwierdzenie występowania aberracji chromosomu pary 8 i 11 pary powinno nasuwać przypuszczenie obecności mutacji genu $A S X L 1$. Inną, ważną w stratyfikacji ryzyka u pacjentów informacją jest fakt, że niektóre aberracje chromosomowe mogą też się wykluczać z mutacją $A S X L 1$, jak w przypadku inwersji chromosomu 16 (13).

Biorąc pod uwagę fakt, że badanie kariotypu jest pierwszym badaniem, jakie jest wykonywane u pacjentów podczas szczegółowej diagnostyki AML, warto zwrócić uwagę na obecność wyżej wymienionych aberracji chromosomowych. W szczególności istotne jest przeanalizowanie aberracji chromosomów 8 i 11, które same świadczą o odpowiednio pośrednim lub niskim ryzyku dla chorego (2), jednak w połączeniu z mutacją genu $A S X L 1$ rokowanie może nie wypadać tak korzystnie. Wykonanie dodatkowej analizy molekularnej genu $A S X L 1$ może zatem dostarczyć wartościowych prognostycznie informacji.

\section{Szczegółowa ocena czynników ryzyka w AML z mutacją genu $A S X L 1$}


Istnieją czynniki, które znacząco wpływają na przeżywalność (OS, ang. overall survival) oraz przeżycie wolne od objawów (EFS, ang. event-free survival) u pacjentów $\mathrm{z}$ uprzednio zdiagnozowaną ostrą białaczką szpikową z mutacją genu $A S X L 1$. Do czynników, które mogą negatywnie wpływać na przeżywalność w tej grupie chorych należą: wiek powyżej 60 lat (14), płeć męska, liczba krwinek białych wynosząca więcej niż $50 \times 10^{9} / \mathrm{L}$, współistniejące mutacje takie jak: mutacje FLT3-ITD, mutacje RUNX1, nieobecność genu fuzyjnego AML1-ETO (15). Nie odbiegają one od tych, które są powszechnie uznane za czynniki wpływające na gorsze rokowanie w ogóle populacji pacjentów z AML.

Wraz z wzrostem ilości obecnych czynników wysokiego ryzyka u pacjenta z mutacją genu ASXL1 w AML następuje pogorszenie prognozy odnośnie przeżywalności oraz przeżywalności wolnej od objawów u pacjentów. OS osób, które wykazywały obecność 1 czynnika ryzyka wynosił 29,53 miesięcy (16). Natomiast u osób, które wykazywały obecność 2 czynników wartość ta wynosiła jedynie 6,67 miesięcy. EFS u pacjentów z 1 czynnikiem ryzyka wynosiła 29,53 miesięcy, 2 czynników - 5,47 miesięcy (16). Można zatem wnioskować, że występowanie większej ilości czynników wysokiego ryzyka u pacjenta znacząco obniża przeżywalność pacjentów oraz przeżycie wolne od objawów. W przypadku występowania jedynie jednego dodatkowego czynnika ryzyka pacjenci nie wykazują nawrotu objawów przed zakończeniem okresu przeżywalności (16).

W grupie pacjentów w wieku 18-61 lat wykazano, że zwiększona częstość występowania mutacji genu $A S X L 1$ jest związana z starszym wiekiem, płcią męską, wtórną ostrą białaczką szpikową, niższym odsetkiem komórek blastycznych. Mutacje $A S X L 1$ współwystępują z mutacjami RUNX1 (17), IDH2 oraz SRSF2, co negatywnie wpływa na OS pacjentów (18). Istnieje jednak wykluczenie pomiędzy mutacją $A S X L 1$ a mutacjami genów $N P M 1(19,20)$, FLT3-ITD i DNMT3A. Pacjenci z mutacją genu ASXL1 w porównaniu z populacją pacjentów bez tej mutacji posiadali niższy wskaźnik remisji o $18 \%$, niższy EFS w ciągu 5 lat o 13,1\%, niższy OS w ciągu 5 lat o 15,4\% (13). Rozpatrując mutacje w genach $A S X L 1$ i $R U N X 1$ osobno, nie mają one znaczącego wpływu na rokowanie pacjentów. Jednakże jeżeli mutacje te występują jednoczasowo to znacząco wzrasta ryzyko śmierci pacjentów, dlatego współistnienie mutacji $R U N X 1 \mathrm{z}$ mutacją $A S X L 1$ stanowi znacząco negatywny czynnik prognostyczny w AML.

\section{Leczenie AML z mutacją genu $A S X L 1$}

Strategia leczenia AML zależy od grupy ryzyka, do której zakwalifikowany został pacjent, jak również podyktowana jest obecnością aberracji chromosomowych i obecnością mutacji genów. Od lat osiemdziesiątych XX w. leczenie AML u większości pacjentów opiera się na trzech kluczowych etapach: indukcji remisji, konsolidacji remisji i leczeniu podtrzymującym (21). W grupie wybranych chorych przeprowadza się allogeniczną transplantację szpiku/krwiotwórczych komórek macierzystych (allo-HSCT, ang. allogenous hematopoietic stem cell tranplanation) celem wyleczenia choroby (2).

Zmiany molekularne w genach NPM1, CEBPA, FLT3, IDH1/2, TP53, RUNX1 i ASXL1 dostarczają ważnych informacji prognostycznych i terapeutycznych, wliczając $\mathrm{w}$ to plan leczenia, zalecenia dotyczące przeszczepu oraz znaczenie wykrywania minimalnej choroby resztkowej (MRD, ang. minimal residual disease). Analiza skutku występowania mutacji umożliwiła opracowanie nowych leków ukierunkowanych molekularnie (22). Obecnie jedynym inhibitorem białka ASLX jest gilterytynib. Farmaceutyk ten podaje się pacjentom, których komórki nowotworowe posiadają mutację w genach dla białka ASLX i FLT3. Gilterytynib blokuje działanie kinaz tyrozynowych kontrolujących wzrost i podział 
leukocytów, co jest korzystne ze względu na obserwowaną nadmierną aktywność i stymulację wzrostu tych krwinek. Postuluje się, że poprzez inhibicję kinazy białkowej gilterytynib zatrzymuje wzrost leukocytów, tym samym spowalniając rozwój choroby (22). Zważając na mnogość mutacji genetycznych, występujących u pacjentów $\mathrm{z}$ AML, terapia celowana powinna stanowić nieodłączny element konwencjonalnej chemioterapii opartej na antracyklinach i cytarabinie (23).

Przeszczepienie komórek krwiotwórczych u pacjentów z chorobami szpiku jest leczeniem pożądanym. Rodzaj przeszczepu, a także czas wykonania zabiegu zależy głównie od rodzaju jednostki chorobowej, wieku pacjenta i chorób współistniejących. Przeżywalność chorych po 55 roku życia, którzy zostali poddani HSCT jest znacznie gorsza niż w populacji pacjentów młodszych (24). Z tego względu górna granica wieku konwencjonalnych HSCT wynosi 55-60 lat. Badania wykazują jednak znaczną poprawę przeżywalności pacjentów z AML z współistniejącą mutacją genu $A S L X 1$ po zastosowaniu przeszczepu allogenicznego. W konsekwencji, warto rozważyć wykonanie przeszczepienia, pomimo mediany wieku w chwili rozpoznania wynoszącej około 65 lat (25).

\section{Podsumowanie}

Obserwowany w ostatnich latach dynamiczny rozwój technik diagnostyki genetycznej pozwala na coraz to głębsze zrozumienie patomechanizmów stojących za rozwojem AML. Rosnąca dostępność molekularnych badań diagnostycznych sprawia, że chorzy mogą być coraz bardziej dokładnie oceniani pod względem rokowania, a wybierane leczenie jest personalizowane w sposób optymalny dla konkretnego pacjenta. Wiedza na temat wpływu obecności mutacji genu $A S X L 1$ na przebieg choroby sprawia, że jego badanie może dołączyć w przyszłości do kluczowych badań wykonywanych podczas wstępnej diagnostyki choroby. Dodatkowe nadzieje budzi opracowywanie leków celowanych molekularnie, charakteryzujących się niższą toksycznością niż standardowa chemioterapia, a zarazem wysoką efektywnością. Personalizacja leczenia oraz dokładniejsze dobieranie pacjentów kandydujących do zabiegu allo-HSCT może w przyszłości w znacznym stopniu poprawić wyniki leczenia AML.

\section{Piśmiennictwo}

1. Conway O'Brien E, Prideaux S, Chevassut T. The epigenetic landscape of acute myeloid leukemia. Adv Hematol. 2014;2014 :103175. doi: 10.1155/2014/103175.

2. Heuser M, Ofran Y, Boissel N, Brunet Mauri S, Craddock C, Janssen J, Wierzbowska A, Buske C; ESMO Guidelines Committee. Electronic address: clinicalguidelines@esmo.org. Acute myeloid leukaemia in adult patients: ESMO Clinical Practice Guidelines for diagnosis, treatment and follow-up. Ann Oncol. 2020 Jun;31(6):697-712. doi: 10.1016/j.annonc.2020.02.018. Epub 2020 Mar 17. Erratum in: Ann Oncol. 2021 Jun;32(6):821

3. Arber DA, Orazzi A, Hasserjian R, Thiele J, Borowitz MJ, Le Beau M, et al. WHO Classification 2016 - Myeloid neoplasms and acute leukemia. Blood. 2016;127(20):2391-405. doi: 10.1182/blood-2016-03-643544

4. Parkin B, Ouillette P, Yildiz M, Saiya-Cork K, Shedden K MS. Integrated genomic profiling, therapy response, and survival in adult acute myelogenous leukemia. Clin Cancer Res. 2015;21(9):2045-56. doi: 10.1158/1078-0432.CCR-14-0921 
5. Kakosaiou K, Panitsas F, Daraki A, Pagoni M, Apostolou P, Ioannidou A, et al. ASXL1 mutations in AML are associated with specific clinical and cytogenetic characteristics. Leuk Lymphoma [Internet]. 2018;59(10):2439-46. Available from: https://doi.org/10.1080/10428194.2018.1433298

6. Asada S, Fujino T, Goyama S, Kitamura T. The role of ASXL1 in hematopoiesis and myeloid malignancies. Cell Mol Life Sci [Internet]. 2019;1(0123456789). Available from: https://doi.org/10.1007/s00018-019-03084-7

7. Yu J, Li Y, Li T, Li Y, Xing H, Sun H, et al. Gene mutational analysis by NGS and its clinical significance in patients with myelodysplastic syndrome and acute myeloid leukemia. Exp Hematol Oncol [Internet]. 2020;9(1):1-11. Available from: https://doi.org/10.1186/s40164-019-0158-5

8. Zbiorowa P. Wytyczne postępowania diagnostyczno-terapeutycznego u chorych na nowotwory układów krwiotwórczego i chłonnego 2020 [Internet]. VM Media Sp z o.o. VM Group sp.k. (Grupa Via Medica); 2020. 119-144 p. Available from: http://onkologia.zalecenia.med.pl/pdf/zalecenia_PTOK_tom2_1.10.Ostra_bialaczka_sz pikowa_200520.pdf Polish.

9. Scheuermann JC, de Ayala Alonso AG, Oktaba K, Ly-Hartig N, McGinty RK, Fraterman S, Wilm M, Muir TW MJ. Histone H2A deubiquitinase activity of the Polycomb repressive complex PR-DUB. Nature. 2010;465(7295):243-7. doi: 10.1038 /nature08966

10. Abdel-Wahab O, Adli M, LaFave LM, Gao J, Hricik T, Shih AH, Pandey S, Patel JP, Chung YR, Koche R, Perna F, Zhao X, Taylor JE, Park CY, Carroll M, Melnick A, Nimer SD, Jaffe JD, Aifantis I, Bernstein BE LR. ASXL1 mutations promote myeloid transformation through loss of PRC2-mediated gene repression. Cancer Cell. 2012;22(2):180-93. doi: 10.1016/j.ccr.2012.06.032

11. Veneti Z, Gkouskou KK, Eliopoulos AG. Polycomb repressor complex 2 in genomic instability and cancer. Int J Mol Sci. 2017;18(8):1-16. doi:10.3390/ijms 18081657

12. Alpermann T, Haferlach C, Eder C, Nadarajah N, Meggendorfer M, Kern W, et al. AML with gain of chromosome 8 as the sole chromosomal abnormality ( +8 sole) is associated with a specific molecular mutation pattern including ASXL1 mutations in $46.8 \%$ of the patients. Leuk Res [Internet]. 2015;39(3):265-72. Available from: http://dx.doi.org/10.1016/j.leukres.2014.11.026

13. Paschka P, Schlenk RF, Gaidzik VI, Herzig JK, Aulitzky T, Bullinger L, et al. ASXL1 mutations in younger adult patients with acute myeloid leukemia: A study by the German-Austrian acute myeloid leukemia study group. Haematologica. 2015;100(3):324-30. doi: 10.3324/haematol.2014.114157

14. Metzeler KH, Becker H, Maharry K, Radmacher MD, Kohlschmidt J, Mrózek K, et al. ASXL1 mutations identify a high-risk subgroup of older patients with primary cytogenetically normal AML within the ELN Favorable genetic category. Blood. 2011;118(26):6920-9. doi: 10.1182/blood-2011-08-368225

15. Chou WC, Huang HH, Hou HA, Chen CY, Tang JL, Yao M, et al. Distinct clinical and biological features of de novo acute myeloid leukemia with additional sex comb-like 1 (ASXL1) mutations. Blood. 2010;116(20):4086-94. doi: 10.1182/blood-2010-05- 
16. Fan Y, Liao L, Liu Y, Wu Z, Wang C, Jiang Z, et al. Risk factors affect accurate prognosis in ASXL1-mutated acute myeloid leukemia. Cancer Cell Int [Internet]. 2021;21(1):1-9. Available from: https://doi.org/10.1186/s12935-021-02233-y

17. Bera R, Chiu MC, Huang YJ, Lin TH, Kuo MC, Shih LY. RUNX1 mutations promote leukemogenesis of myeloid malignancies in ASXL1-mutated leukemia. J Hematol Oncol. 2019;12(1):1-18. doi:10.1186/s13045-019-0789-3

18. Richardson DR, Swoboda DM, Moore DT, Johnson SM, Chan O, Galeotti J, et al. Genomic characteristics and prognostic significance of co-mutated ASXL1/SRSF2 acute myeloid leukemia. Am J Hematol. 2021;96(4):462-70. doi: 10.1002/ajh.26110

19. Papaemmanuil E, Ph D, Gerstung M, Ph D, Bullinger L, Gaidzik VI, et al. Europe PMC Funders Group Genomic Classification and Prognosis in Acute Myeloid Leukemia. 2016;374(23):2209-21. 10.1056/NEJMoa1516192

20. Carbuccia N, Trouplin V, Gelsi-Boyer V, Murati A, Rocquain J, Adélade J, et al. Mutual exclusion of ASXL1 and NPM1 mutations in a series of acute myeloid leukemias. Leukemia. 2010;24(2):469-73. doi: 10.1038/leu.2009.218

21. DiNardo CD, Stein EM, de Botton S, Roboz GJ, Altman JK, Mims AS, et al. Durable Remissions with Ivosidenib in IDH1 -Mutated Relapsed or Refractory AML. N Engl J Med. 2018;378(25):2386-98. DOI: 10.1056/NEJMoa1716984

22. Pratz K, Cherry M, Altman JK, Cooper BW, Cruz JC, Jurcic JG, Levis MJ, Lin TL, Perl AE, Podoltsev NA, Schiller GJ, Liu C, Bahceci E. Preliminary Results from a Phase 1 Study of Gilteritinib in Combination with Induction and Consolidation Chemotherapy in Subjects with Newly Diagnosed Acute Myeloid Leukemia (AML). $\begin{array}{lllll}\text { Blood 2017; } & 130 & \text { (Supplement } & \text { 1): }\end{array}$ doi: https://doi.org/10.1182/blood.V130.Suppl_1.722.722

23. DiNardo C, Lachowiez C. Acute Myeloid Leukemia: from Mutation Profiling to Treatment Decisions. Curr Hematol Malig Rep. 2019;14(5):386-94. doi: 10.1007/s11899-019-00535-7

24. Aoki J, Kanamori H, Tanaka M, Yamasaki S, Fukuda T, Ogawa H, et al. Impact of age on outcomes of allogeneic hematopoietic stem cell transplantation with reduced intensity conditioning in elderly patients with acute myeloid leukemia. Am J Hematol. 2016;91(3):302-7. doi: 10.1002/ajh.24270

25. Zhou L, An J, Hou C, Ding Z, Qiu H, Tang X, et al. Allogeneic hematopoietic stem cell transplantation could improve the survival of acute myeloid leukemia patients with ASXL1 mutations. Hematol (United Kingdom). 2021;26(1):340-7. doi: 10.1080/16078454.2021.1905356 